\title{
Professional Connections within Analyst Teams and Forecast Accuracy
}

\author{
Xianjiao $\mathrm{Wu}$ \\ Harbin Institute of Technology \\ xianjiaowu@hit.edu.cn
}

\author{
Hong Hong \\ Harbin Institute of Technology \\ honghong@hit.edu.cn
}

\author{
Qiang Ye \\ Harbin Institute of Technology \\ yeqiang@hit.edu.cn
}

\begin{abstract}
Understanding factors associated with the performance of the sell-side analyst is of great value in both theory and practice. We profile the crucial influence of professional connections among security analysts on generating earnings forecast in this study based on a dataset of analysts' employment history obtained from the Securities Association of China and analysts' history forecasts obtained from CSMAR. By estimating a multivariate linear regression model, we find that professional connections within analyst teams are positively associated with earnings forecast accuracy. The results of Fisher's Permutation test further confirm that the effect of professional connections on analyst forecast quality is stronger when firms covered are facing decreasing EPS. Our results still hold for additional analyses with an alternative measure for professional connections. In conclusion, this work confirms the significant role of professional connections in information sharing and mutual understanding among analysts.
\end{abstract}

\section{Introduction}

To enhance their reputation and improve their service to customers, security firms invest a lot of money in securities research [68]. They employ analysts to be engaged in the security research, issue earnings forecasts and stock recommendations, and produce research reports [47]. Sell-side analysts are usually more experienced and professional in information collecting and data analyzing [35]. They strive to perform better to be prominent in the analyst ranking battle and competitive for the position in top brokerage firms [54]. Accordingly, analysts are considered as major components of brokerage firms, as well as an indispensable part in the stock market [29, 47, 54].

Given the analysts' indelible contributions to asset pricing and information dissemination [26, 40, 48], there are a wealth of research exploring the analysts' behavior $[27,34,45,65]$, their outputs $[29,35,50,64$, 68], and the market reaction to analysts' research report $[51,58]$. The quality of analyst reports, especially the forecast accuracy, is of interest to security firms, listed companies, and investors. It is well documented in previous literature that the macroeconomic situation (e.g., financial crisis or economic recession) [49], characteristics of listed companies (e.g., the size and profitability of firms) [25, 48] and brokerage houses [7], and analyst-level heterogeneity (e.g., the industry knowledge, experience, and gender) $[6,7,9,44]$ could exert impact on analyst forecast accuracy in different ways. While a significant portion of forecasts are issued by analyst teams, the effect of teamwork and characteristics of analyst teams on analyst research quality receives scant attention in existing literature.

In particular, the connection network within teams is becoming increasingly close and complex because of the rapid development of information and internet technology. Ample evidence proves that the connection is helpful to improve the performance of teams by promoting information sharing and enhancing mutual understanding among team members in many fields [ 16 , 24]. And the effect of connections on performance could be different due to various environment [42]. Although extant studies demonstrate that social connections and school ties within teams are influential to the team behavior and performance. Another important type of connection, the professional connections, receive little attention especially in context of security analysts. Furthermore, unlike school ties or social connections, professional connections can better reflect common knowledge and experience that are related to tasks. Hence, it is of great value to explore the influence of professional connections on forecast accuracy in context of security analyst earnings forecast.

Considering the significant value of analyst forecast accuracy to both academia and industry, this study attempts to fill this gap by shedding light on the following two specific research questions: (1) Whether professional connections within analyst teams boost their forecast accuracy or not? And if so, (2) whether the impact of professional connections on forecast accuracy is stronger when the forecasted firms are in face of 
decrease in EPS?

We measure professional connections within analyst teams based on a dataset of analysts' history employment information and analyst forecasts from 2016 to 2017. Our findings demonstrate that the professional connections are associated with higher earnings forecast accuracy, and this relationship is stronger when firms covered are facing decreasing EPS. This work makes theoretical contributions by enriching the literature on the analyst behavior and their performance from a novel perspective. This work also has practical implications for the analyst grouping in the security firms and analyst performance evaluating by the investors.

The rest of this paper is organized as follows. Firstly, we systematically review related literature and logically deduce our hypotheses based on previous studies in section 2. Section 3 describes the data source and the measurement of variables employed in this study. We also specify our model in this part. We summarize the descriptive statistics and report main analysis results in the fourth part of this paper. The results of robustness check are presented in section 5. Section 6 concludes our findings. Finally, we discuss our contributions to both academics and practitioners, limitations of this work, and future research opportunities in Section 7.

\section{Related work and hypotheses development}

Security firms and analysts conduct analysis and research about listed firms based on the information concerning firms, industries and the macro-environment [68]. However, it is time consuming to collect and analyze information due to the explosive information with much noise. Therefore, more and more research reports, recommendations, and forecasts are issued by analyst teams as teamwork is proved to be helpful in knowledge production [38, 63].

The connections within teams, which implies the similar background and common experience, inspire a wave of research on the role of connection network [42]. Substantial evidence demonstrates that the shared experience and similar knowledge background significantly enhance communication and collaboration among team members, promote information sharing within teams, and ultimately improve the team performance $[11,53]$. In addition, the connected team members are usually familiar with each other. The relationships among them breed better mutual understanding and greater mutual trust $[11,17,62]$, which convert into higher quality of team performance as well.

The generation of security analyst earnings forecast is a complicated process, which involves information collecting, sharing, and analyzing. Information sharing is widely recognized as the premise of collaborative working $[10,55]$. A body of relevant literature can be classified into two clusters according to different conceptual and operational definitions of information sharing. Based on the description of the uniqueness of information sharing [28], a series of studies argue that information sharing will enrich analysts' knowledge background, experience diversity, and information sources of teams, leading to better teams' performance [61]. The other group of research about the openness of information sharing believes that it will improve the teams' performance by facilitating the communication among team members while they are working together on a task $[1,36]$. Moreover, information sharing can also help in boosting analyst team performance through enhancing the trust and cohesion among team members and coordinating the teams' work [5]. The information processing on basis of information collecting and sharing is also crucial to forecast accuracy of analyst teams. Mutual understanding and trust among connected analysts make contribution to better performance by eliminating communication barriers and reducing misunderstanding during data analyzing. Therefore, we put forward the following assumption.

Hypothesis 1. Professional connections within analyst team are positively associated with analysts' earnings forecast accuracy.

It is not news that firms tend to disclose information strategically especially when firms are in face of adversity [39]. On one hand, top managers tilt to withhold bad news due to career concerns and personal wealth $[3,4,31,43]$. On the other hand, firms may voluntarily disclose bad news to maintain the company reputation and avoid risk of litigation [12]. The asymmetric dissemination leads to more complicated firm information environment during the bad time.

What's more, bad news has wings! Existing literature indicates that the financial press and social media prefer to deliver sensational information of firms with poor financial performance $[2,59]$. The competation for readers' attention drives media coverage to sacrifice the accuracy and objectivity. Besides, the bad news, which implies risk, would diffuse faster among family, friends, collegues, and be amplified due to the dread of risk [12,33].

In a word, there will be information explosion for both valuable information and noise, when firms are not doing well. For analyst teams without professional connections, the complex and uncertain information environment of firms in bad times makes it diffcult for them to collect and identify useful information, thus resulting in larger forecast error [49]. In contrast, professional connected analyst teams can handle the 
complex information better using collective knowledge. First, information sharing and explosive information during bad time also provide more data for professional connected analyst teams to process and analyze. Second, mutual understanding and trust within teams promote communication, reduce bias, and help in identification of valid information. Further, professional connections may bring more common value and perspectives, which helps a team reach consensus quickly.

Therefore, the integration of information resources [28], sharing of knowledge and experience [11, 53], and consensus on methods of information processing $[1,36]$ within professional connected analyst teams are even more valuable in improving analyst forecast accuracy when forecasted firms are in distress. Hence, we propose the following hypothesis.

Hypothesis 2. The effect of analysts' professional connections within a team on forecast accuracy is larger when forecasted firms face decrease in EPS.

\section{Research methodology}

\subsection{Data collection}

The data of security analyst and earnings forecast used in this study comes from the website of the Securities Association of China and CSMAR, respectively.

To measure professional connections within analyst teams, we collect basic information of practitioners from the website of the Securities Association of China (http://www.sac.net.cn/) with a crawler developed in Python. It offers historical records of security analysts in details, including their names, job titles, brokerage houses they worked for, the time when they joined the companies, and some other personal information. We totally obtain 8,341 career records of 2,955 analysts from 74 brokerage houses dating back to August 2003.

To investigate the influence of professional connections on the forecast accuracy, we obtain the data of earnings forecast error throughout 2016 to 2017 from CSMAR database. We rule out earnings forecasts for the next two years and conduct analysis only on earnings forecasts for current year to avoid the exogenous influence induced by macroeconomic. We obtain 94,476 forecast records of 4,533 analyst (teams) working for 75 brokerage houses in total.

Following existent studies [19, 23, 27, 42, 46, 49], we also control other factors at firm level (e.g., variables that reflect financial status of firms as well as their popularity among analysts), analyst level (e.g., variables that measure the experience and reputation of analysts), and brokerage house level (e.g., variable that reflects the size of brokerage houses), which probably have effect on analyst forecast accuracy. Additional data of control variables are obtained from CSMAR. After excluding the data with missing values and conversions of variables, there are 60,996 forecasts for firms in China' A-share market issued by 2523 analyst (teams) in our initial dataset. To investigate the role of connections within analyst teams, we exclude the forecasts issued by individual analysts, and finally reach to a sample of 19,129 observations from 2016 to 2017 .

\subsection{Variable measures}

3.2.1 Dependent variables. Based on Loh and Stulz (2018) [49], we utilize forecast errors to measure the earnings forecast accuracy, which is calculated as the absolute difference between forecasted and actual earnings per share, divided by the absolute value of actual earnings per share. We multiply the forecast error by -1 to better explain the effect of professional connections on analyst forecast. Specificly, the forecast accuracy is calculated as follows:

$$
\text { Accuracy }=(-1) * \frac{\mid \text { Forecasted EPS }- \text { Actual EPS } \mid}{\mid \text { Actual EPS } \mid}
$$

where Forecast EPS is the earnings per share of the stock forecasted by analyst, whereas Actual EPS is the actual earnings per share for the given stock by the analyst.

3.2.2 Independent variables. The main purpose of our analysis is to examine the role of professional connections among analyst teams. Following prior studies [22, 24, 42], we define two analysts as professional connected if they have worked for the same brokerage house before. We employ an indicator variable that equals to one if any two analysts within a team are connected, and zero otherwise.

$$
\text { Connection }= \begin{cases}1, & \text { if any two analysts are connected } \\ 0, & \text { otherwise }\end{cases}
$$

3.2.3 Control variables. To control the effect of listed firm operation performance on forecast accuracy, we introduce an indicator variable which equals to one when the EPS of the firm is lower than its value in last year, and zero otherwise.

$$
\text { Decrease }= \begin{cases}1, & \text { if } E P S_{t}<E P S_{t-1} \\ 0, & \text { otherwise }\end{cases}
$$

To control for other factors that have been documented to be related to the forecast accuracy, some control variables reflecting the heterogeneity of analysts and brokerage houses, as well as firm level characteristics are introduced into our model $[14,15,19$, 23, 27, 41, 42, 46, 49].

The measurement of all variables and source of data involved in this study are presented in Table 1. 
Table 1. Measurements and source of variables

\begin{tabular}{|c|c|c|}
\hline Variables & Measures & Source \\
\hline \multicolumn{3}{|l|}{ Dependent Variables } \\
\hline Accuracy & $\begin{array}{l}\text { We gauge the earnings forecast accuracy as forecast error multiplied by }-1 \text {. Where forecast } \\
\text { error is calculated as the absolute difference between actual and forecasted earnings per share, } \\
\text { scaled by the absolute value of actual earnings [ } 49] \text {. }\end{array}$ & CSMAR \\
\hline \multicolumn{3}{|l|}{ Independent Variables } \\
\hline Connection & $\begin{array}{l}\text { Professional connection is specified as one if any two analysts within the analyst team both } \\
\text { worked in another same brokerage, and their tenures there are overlapped. Connection equals } \\
\text { to zero otherwise [42]. }\end{array}$ & http://www.sac.net.cn/ \\
\hline \multicolumn{3}{|l|}{ Control Variables } \\
\hline Decrease & $\begin{array}{l}\text { A firm level dummy variable that equals to one if the EPS of the firm is lower than EPS in the } \\
\text { previous year, and zero otherwise }[19,42] \text {. }\end{array}$ & CSMAR \\
\hline Star & $\begin{array}{l}\text { An indicator variable that reflects the reputation of analysts. It equals to one for analyst who is } \\
\text { voted star analyst during of the year of forecasts, and zero otherwise }[23,49] \text {. }\end{array}$ & CSMAR \\
\hline BrokerageSize & $\begin{array}{l}\text { The number of analysts at the brokerage that issued earnings forecasts during the year of } \\
\text { forecasts. The log value is used in regressions }[23,49] \text {. }\end{array}$ & CSMAR \\
\hline Experience & $\begin{array}{l}\text { The experience of analysts which is measure with the number of years from the analysts issued } \\
\text { the first earnings forecast until the year of forecast is issued. The log value is used in } \\
\text { regressions }[23,27] \text {. }\end{array}$ & CSMAR \\
\hline No_Firms & $\begin{array}{l}\text { Number of firms that analysts issue an earnings forecast during the year of the forecast. The } \\
\log \text { value is used in regressions }[23,46] .\end{array}$ & CSMAR \\
\hline$B M$ & $\begin{array}{l}\text { Book-to-market ratio which is calculated as book value divided by size. The value during the } \\
\text { previous year of the forecast is used in regressions. }\end{array}$ & CSMAR \\
\hline$R O A$ & $\begin{array}{l}\text { A measurement of operation conditions of listed firms. Return on assets which is calculated as } \\
\text { net profit/balance of stockholder's equity. The value during the previous year of the forecast is } \\
\text { used in regressions. }\end{array}$ & CSMAR \\
\hline PastRet & Annual return of the stock covered by analysts during the previous year of the forecast. & CSMAR \\
\hline Analyst_Following & $\begin{array}{l}\text { Number of other analysts who issue forecasts for the company during the previous year of } \\
\text { forecast. The log value is used in regressions [23]. }\end{array}$ & CSMAR \\
\hline
\end{tabular}

\subsection{Model development}

To test our hypothesis on the relationship between professional connections and forecast accuracy, we first develop a multivariate linear regression model to analyze our report level observation dataset [30]. Specifically, we utilize the ordinary least square method to estimate the following regression equation of forecast accuracy on professional connection and a set of control variables. All the variables in Equation (4) are defined in Table 1. We additionally include year fixed effect in the regression.

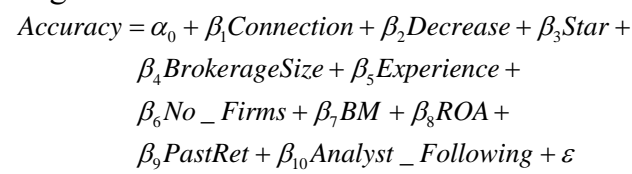

To further understand the impact of professional connections on forecast accuracy when firms are in different operation environment and test our second hypothesis, we split the sample into two groups according to the value of Decrease. To determine the significant level of differences between coefficients across two groups, we again estimate the above model and conduct the Fisher's Permutation test with the bootstrap sampling procedure $[13,20]$.

\section{Data analysis and results}

\subsection{Descriptive statistics}

Our initial sample consists of 60,996 observations of earnings forecasts for firms in China's A-share stock market from 2016 to 2017. About one third of forecasts are issued by analyst teams while the others are issued by single analyst. The mean of forecast accuracy from analyst teams $(-0.591)$ is slightly higher than the mean of accuracy from single analyst $(-0.595)$. We further summary statistics for earnings forecasts issued by analyst teams when firms are in different operation environment in Table 2. After ruling out forecasts issued by single analyst, we find that the ratio of connected analyst teams in our sample is only about 9.44 percent, which is lower than the proportion of network connected directors in prior studies. This probably because they also take into account education connections [42], the current employment and other types of connections [24].

Besides, the analyst teams with professional connections in our dataset (mean $=-0.46$ ) are more accurate than those without professional connections (mean $=-0.60$ ), initially confirming our suspicion of the relationship between the professional connections and forecast accuracy. Specifically, the forecast accuracy is lower when firms have poor operation performance, suggesting that it is harder for analysts to forecast precisely during bad time. It is worth noting that for firms facing decrease in EPS, professional connected analyst teams perform better in forecasting than teams 
Table 2. Descriptive statistics for earnings forecast accuracy issued by analyst teams

\begin{tabular}{|c|c|c|c|c|c|c|c|c|c|c|c|c|}
\hline \multirow{3}{*}{ Variable } & \multicolumn{6}{|c|}{ Connection $=0$} & \multicolumn{6}{|c|}{ Connection $=1$} \\
\hline & \multicolumn{2}{|c|}{$\begin{array}{c}\text { Full Sample } \\
\text { Obs } \#=17,323\end{array}$} & \multicolumn{2}{|c|}{$\begin{array}{c}\text { Decrease }=0 \\
\text { Obs } \#=10,995\end{array}$} & \multicolumn{2}{|c|}{$\begin{array}{l}\text { Decrease }=1 \\
\text { Obs\# = 6,328 }\end{array}$} & \multicolumn{2}{|c|}{$\begin{array}{l}\text { Full Sample } \\
\text { Obs\# =1,806 }\end{array}$} & \multicolumn{2}{|c|}{$\begin{array}{l}\text { Decrease }=0 \\
\text { Obs\# }=1,180\end{array}$} & \multicolumn{2}{|c|}{$\begin{array}{c}\text { Decrease }=1 \\
\text { Obs\# }=626\end{array}$} \\
\hline & Mean & S.D. & Mean & S.D. & Mean & S.D. & $\begin{array}{c}\text { Mea } \\
\mathrm{n}\end{array}$ & S.D. & Mean & S.D. & Mean & S.D. \\
\hline Accuracy & -0.60 & 1.38 & -0.33 & 0.92 & -1.08 & 1.84 & -0.46 & 1.07 & -0.23 & 0.64 & -0.91 & 1.50 \\
\hline Star & 0.10 & 0.30 & 0.09 & 0.29 & 0.10 & 0.30 & 0.18 & 0.38 & 0.16 & 0.37 & 0.21 & 0.41 \\
\hline BrokerageSize & 4.03 & 0.50 & 4.04 & 0.50 & 4.01 & 0.50 & 4.06 & 0.40 & 4.05 & 0.40 & 4.06 & 0.39 \\
\hline Experience & 0.72 & 0.38 & 0.72 & 0.39 & 0.73 & 0.36 & 0.74 & 0.38 & 0.73 & 0.37 & 0.77 & 0.38 \\
\hline No_Firms & 2.73 & 0.78 & 2.73 & 0.77 & 2.73 & 0.80 & 3.00 & 0.85 & 2.96 & 0.85 & 3.08 & 0.84 \\
\hline$B M$ & 0.97 & 1.97 & 1.00 & 1.84 & 0.93 & 2.19 & 0.85 & 1.01 & 0.98 & 1.13 & 0.61 & 0.67 \\
\hline$R O A$ & 0.06 & 0.05 & 0.05 & 0.05 & 0.07 & 0.05 & 0.06 & 0.05 & 0.06 & 0.04 & 0.07 & 0.05 \\
\hline PastRet & 0.32 & 0.76 & 0.31 & 0.74 & 0.34 & 0.79 & 0.25 & 0.79 & 0.20 & 0.66 & 0.35 & 0.98 \\
\hline $\begin{array}{l}\text { Analyst_- } \\
\text { Following }\end{array}$ & 2.49 & 0.75 & 2.48 & 0.78 & 2.51 & 0.70 & 2.50 & 0.71 & 2.51 & 0.73 & 2.48 & 0.67 \\
\hline
\end{tabular}

without connection, providing preliminary evidence for Hypothesis 2. Another interesting finding is that the mean of Star in the connected group is twice as that in the non-connected group.

The correlation coefficients between all the variables in our study are presented in Table 3 . We can get a glimpse of the influence of professional connections on forecast accuracy from the significant positive correlation coefficient (0.02) between Accuracy and Conn, which is consistent with the fact in Table 2.

To test for the multicollinearity between independent variables and control variables, we calculate and show VIF values between them at the bottom of Table 3 . It is obvious that there is no multicollinearity between variables as VIF values are far less than 10 [52].

\subsection{Main analysis}

Table 3. Correlation coefficients of all variables and VIF values

\begin{tabular}{|c|c|c|c|c|c|c|c|c|c|c|c|}
\hline & V1 & $\mathrm{V} 2$ & V3 & V4 & V5 & V6 & V7 & V8 & V9 & V10 & V11 \\
\hline V1: Accuracy & 1.00 & & & & & & & & & & \\
\hline V2: Conn & $0.03^{*}$ & 1.00 & & & & & & & & & \\
\hline V3: Decrease & $-0.26^{*}$ & -0.01 & 1.00 & & & & & & & & \\
\hline V4: Star & $-0.03^{*}$ & $0.08^{*}$ & $0.02^{*}$ & 1.00 & & & & & & & \\
\hline V5: BrokerageSize & 0.01 & $0.02^{*}$ & $-0.03^{*}$ & $-0.06^{*}$ & 1.00 & & & & & & \\
\hline V6: Experience & $-0.07^{*}$ & $0.02^{*}$ & 0.01 & $0.18^{*}$ & $0.08^{*}$ & 1.00 & & & & & \\
\hline V7: No_Firms & $-0.03^{*}$ & $0.10^{*}$ & 0.01 & $0.26^{*}$ & 0.01 & $0.22^{*}$ & 1.00 & & & & \\
\hline V8: $B M$ & $0.03^{*}$ & $-0.02^{*}$ & $-0.03^{*}$ & $-0.05^{*}$ & $0.07^{*}$ & 0.00 & $-0.04^{*}$ & 1.00 & & & \\
\hline V9: $R O A$ & $0.16^{*}$ & $0.03^{*}$ & $0.12^{*}$ & $0.02^{*}$ & 0.00 & 0.00 & $-0.05^{*}$ & $-0.26^{*}$ & 1.00 & & \\
\hline V10: PastRet & $-0.09^{*}$ & $-0.03^{*}$ & $0.03^{*}$ & $0.03^{*}$ & $-0.08^{*}$ & $-0.02^{*}$ & $-0.02^{*}$ & $-0.16^{*}$ & 0.01 & 1.00 & \\
\hline V11: Analyst_Following & $0.10^{*}$ & 0.00 & 0.01 & $0.02^{*}$ & $0.03^{*}$ & $0.02^{*}$ & $-0.02^{*}$ & $0.08^{*}$ & $0.27^{*}$ & $-0.16^{*}$ & 1.00 \\
\hline VIF & & 1.02 & 1.02 & 1.11 & 1.02 & 1.08 & 1.13 & 1.13 & 1.20 & 1.06 & 1.13 \\
\hline
\end{tabular}

To test our first assumption about forecast accuracy, we estimate the multivariate linear regression model with year fixed effect described in equation (4) on the sample of forecasts issued by analyst teams. The main results are displayed in Table 4.

Model 1 in Table 4 serves as the baseline, which depicts the association between control variables and earnings forecast accuracy. The coefficients of control variables are in line with the result of correlation coefficients matrix. Be consistent with Ertimur et al. (2011) and Merkley et al. (2017) [23, 54], we find it is interesting that the Experience is negative related with the Accuracy, while we always predict that experienced analysts should have better performance. It may because that experienced analysts are too confident to reach consensus, which impairs the team performance. Besides, earnings forecasts of firms followed by more analysts (Analyst_Following) tend to be more accurate 
as analysts probably get additional information or learn from their peers' research reports [37, 67].

Model 2 captures the putative relationship between professional connections within analyst teams and earnings forecast accuracy. As we suspect, the coefficient of Conn in column 2 is positive (0.124) and significant at the level of 0.01 , strongly confirming that professional connections within analyst teams could improve their earnings forecasts quality. Hence, Hypothesis 1 is supported. A plausible interpretation is that professional connections within analyst teams promotes information sharing $[18,66]$ and facilitates mutual understanding and trust $[17,60]$ among analysts.

As prior studies prove that difficult environment may lead to the decline of forecast accuracy [32, 57]. We add the Decrease into regression in Model 3 to control the impact of firm operation performance on forecast accuracy. As Model 3 shows, the coefficient of Decrease is significantly negative $(-0.881)$ at the level of 0.01, consistent with Loh and Stulz (2018) [49]. That is, the forecast will be less accurate when firms suffer decrease in EPS. The association between Conn and Accuracy remains significantly positive (0.118) in Model 3. Besides, the signs of all the other variables' coefficients remain unchanged, suggesting that our model is valid.

In order to test the second hypothesis, we proceed Fisher's Permutation test to explore whether the effect

Table 4. Forecast accuracy and professional connections within the analyst team

\begin{tabular}{|c|c|c|c|}
\hline Variables & $\begin{array}{c}\text { Model } 1 \\
\text { Accuracy }\end{array}$ & $\begin{array}{c}\text { Model } 2 \\
\text { Accuracy }\end{array}$ & $\begin{array}{c}\text { Model } 3 \\
\text { Accuracy }\end{array}$ \\
\hline Conn & & $\begin{array}{c}0.124^{* * * *} \\
(0.033)\end{array}$ & $\begin{array}{c}\mathbf{0 . 1 1 8}^{* * * *} \\
(\mathbf{0 . 0 3 2})\end{array}$ \\
\hline Decrease & & & $\begin{array}{c}-0.811^{\text {***** }} \\
(0.019)\end{array}$ \\
\hline Star & $\begin{array}{c}-0.069^{* *} \\
(0.033)\end{array}$ & $\begin{array}{c}-0.077^{* * *} \\
(0.033)\end{array}$ & $\begin{array}{c}-0.077^{\text {*** }} \\
(0.032)\end{array}$ \\
\hline BrokerageSize & $\begin{array}{c}0.006 \\
(0.020)\end{array}$ & $\begin{array}{c}0.006 \\
(0.020)\end{array}$ & $\begin{array}{l}-0.005 \\
(0.019)\end{array}$ \\
\hline Experience & $\begin{array}{c}-0.246^{* * * *} \\
(0.026)\end{array}$ & $\begin{array}{c}-0.244^{* * *} \\
(0.026)\end{array}$ & $\begin{array}{c}-0.242^{\text {**** }} \\
(0.025)\end{array}$ \\
\hline No_Firms & $\begin{array}{c}0.002 \\
(0.013)\end{array}$ & $\begin{array}{l}-0.002 \\
(0.013)\end{array}$ & $\begin{array}{c}0.003 \\
(0.012)\end{array}$ \\
\hline$B M$ & $\begin{array}{c}0.042^{\text {*** }} \\
(0.005)\end{array}$ & $\begin{array}{l}0.042^{* * * *} \\
(0.005)\end{array}$ & $\begin{array}{l}0.044^{* * * *} \\
(0.005)\end{array}$ \\
\hline$R O A$ & $\begin{array}{l}4.221^{\text {*** }} \\
(0.198)\end{array}$ & $\begin{array}{l}4.205^{* * *} \\
(0.198)\end{array}$ & $\begin{array}{l}5.246^{* * *} \\
(0.191)\end{array}$ \\
\hline PastRet & $\begin{array}{c}-0.117^{* * *} \\
(0.016)\end{array}$ & $\begin{array}{c}-0.119^{* * * *} \\
(0.016)\end{array}$ & $\begin{array}{c}-0.146^{\text {**** }} \\
(0.015)\end{array}$ \\
\hline Analyst_Following & $\begin{array}{c}0.081^{\text {*** }} \\
(0.014)\end{array}$ & $\begin{array}{l}0.082^{* * * *} \\
(0.014)\end{array}$ & $\begin{array}{c}0.078^{* * * *} \\
(0.013)\end{array}$ \\
\hline _cons & $\begin{array}{c}-0.899^{* * *} \\
(0.092)\end{array}$ & $\begin{array}{c}-0.893^{* * *} \\
(0.092)\end{array}$ & $\begin{array}{c}-0.555^{* * * *} \\
(0.088)\end{array}$ \\
\hline Year fixed effects & YES & YES & YES \\
\hline $\mathrm{N}$ & 19,129 & 19,129 & 19,129 \\
\hline $\mathrm{R}^{2}$ & 0.045 & 0.045 & 0.126 \\
\hline
\end{tabular}

Standard errors are reported in parentheses ${ }^{*} p<0.1,{ }^{* *} p<0.05,{ }^{* * *} p<0.01$ of professional connections within analyst teams on forecast accuracy is larger when the firms' EPS is decreasing. The result is presented in Table 5.

Among the sample of forecasts issued by analyst teams from 2016 to 2017 , there are 6,954 observations with Decrease equal to 1 , meaning that these firms are suffering EPS decline. The association between analyst professional connections and forecast accuracy is positive and significant whenever the Decrease is 1 or 0 . However, it is obvious that the effect of professional connections on accuracy is stronger when the Decrease equals to 1 according to the magnitude of coefficients of Conn in column $1\left(\beta_{1}=0.070\right)$ and column $2\left(\beta_{1}=0.242\right)$. Furthermore, the result of Fisher's Permutation test with bootstrap sampling procedure indicates that the difference between coefficients of Conn in two subgroups is significant at the level of 0.01 .

Table 5. Effects of connections on

forecast accuracy in different operation

envi ronment

\begin{tabular}{|c|c|c|c|c|}
\hline Variables & Decrease $=0$ & Decrease $=1$ & Diff & $p$-value \\
\hline Conn & $\begin{array}{l}0.070^{* * * *} \\
(0.027)\end{array}$ & $\begin{array}{l}0.242^{* * * *} \\
(0.074)\end{array}$ & -0.171 & 0.001 \\
\hline Star & $\begin{array}{c}-0.062^{* *} \\
(0.028)\end{array}$ & $\begin{array}{l}-0.081 \\
(0.070)\end{array}$ & 0.019 & 0.366 \\
\hline $\begin{array}{l}\text { Brokerage } \\
\text { Size }\end{array}$ & $\begin{array}{l}-0.010 \\
(0.016)\end{array}$ & $\begin{array}{l}-0.022 \\
(0.043)\end{array}$ & 0.012 & 0.414 \\
\hline Experience & $\begin{array}{c}-0.089^{* * * *} \\
(0.021)\end{array}$ & $\begin{array}{c}-0.507^{* * * *} \\
(0.059)\end{array}$ & 0.418 & 0.000 \\
\hline No_Firms & $\begin{array}{l}0.021^{* *} \\
(0.011)\end{array}$ & $\begin{array}{l}-0.039 \\
(0.028)\end{array}$ & 0.060 & 0.018 \\
\hline$B M$ & $\begin{array}{l}0.029^{* * * *} \\
(0.005)\end{array}$ & $\begin{array}{l}0.064^{\text {**** }} \\
(0.010)\end{array}$ & -0.035 & 0.000 \\
\hline$R O A$ & $\begin{array}{l}4.356^{* * * *} \\
(0.168)\end{array}$ & $\begin{array}{l}7.149^{\text {**** }} \\
(0.423)\end{array}$ & -2.793 & 0.000 \\
\hline PastRet & $\begin{array}{l}-0.005 \\
(0.014)\end{array}$ & $\begin{array}{c}-0.327^{\text {*** }} \\
(0.031)\end{array}$ & 0.321 & 0.000 \\
\hline $\begin{array}{l}\text { Analyst_- } \\
\text { Following }\end{array}$ & $\begin{array}{l}0.032^{* * *} \\
(0.011)\end{array}$ & $\begin{array}{l}0.184^{* * * *} \\
(0.031)\end{array}$ & -0.151 & 0.000 \\
\hline _cons & $\begin{array}{c}-0.646^{* * * *} \\
(0.075)\end{array}$ & $\begin{array}{c}-1.254^{* * * *} \\
(0.204)\end{array}$ & 0.608 & 0.002 \\
\hline $\begin{array}{l}\text { Year fixed } \\
\text { effects }\end{array}$ & YES & YES & & \\
\hline $\mathrm{N}$ & 12,175 & 6,954 & & \\
\hline $\mathrm{R}^{2}$ & 0.072 & 0.078 & & \\
\hline
\end{tabular}

\section{Robustness check}

The focus of this study is professional connections within analyst teams. To test the robustness of our results, an alternative definition of professional connections is developed based on prior study [42]. We introduce an index of connections, Conn index, which is calculated as follows:

$$
\text { Conn_index }=\frac{\text { Number of all the connections }}{\text { Total number of possible connections }}
$$

where the numerator measures the number of all the 
connections between any two members within an analyst team. And the denominator is the total number of possible connections within a team.

We estimate the multivariate linear regression of Accuracy against Conn index, Decrease, and other control variables on the same sample. The coefficient of Conn_index in Table 6 is still significantly positive at the level of 0.01, suggesting that the association of the Conn_index and Accuracy is robust. Besides, the Decrease is negative related with the forecast accuracy, which is in line with the result in Table 4.

\begin{tabular}{|c|c|c|c|}
\hline & $\begin{array}{c}\text { Model } 1 \\
\text { Accuracy }\end{array}$ & $\begin{array}{c}\text { Model } 2 \\
\text { Accuracy }\end{array}$ & $\begin{array}{l}\text { Model } 3 \\
\text { Accuracy }\end{array}$ \\
\hline Conn_index & & $\begin{array}{c}0.1366^{* * *} \\
(0.037)\end{array}$ & $\begin{array}{c}\mathbf{0 . 1 3 2}^{* * * *} \\
(\mathbf{0 . 0 3 6})\end{array}$ \\
\hline Decrease & & & $\begin{array}{c}-0.811^{* * * *} \\
(0.019)\end{array}$ \\
\hline Star & $\begin{array}{l}-0.069^{* *} \\
(0.033)\end{array}$ & $\begin{array}{c}-0.077^{* *} \\
(0.033)\end{array}$ & $\begin{array}{l}-0.078^{* * *} \\
(0.032)\end{array}$ \\
\hline BrokerageSize & $\begin{array}{c}0.006 \\
(0.020)\end{array}$ & $\begin{array}{c}0.005 \\
(0.020)\end{array}$ & $\begin{array}{l}-0.005 \\
(0.019)\end{array}$ \\
\hline Experience & $\begin{array}{c}-0.246^{* * *} \\
(0.026)\end{array}$ & $\begin{array}{c}-0.248^{* * * *} \\
(0.026)\end{array}$ & $\begin{array}{c}-0.245^{\text {*** }} \\
(0.025)\end{array}$ \\
\hline No_Firms & $\begin{array}{c}0.002 \\
(0.013)\end{array}$ & $\begin{array}{l}-0.002 \\
(0.013)\end{array}$ & $\begin{array}{c}0.003 \\
(0.012)\end{array}$ \\
\hline$B M$ & $\begin{array}{c}0.042^{* * * *} \\
(0.005)\end{array}$ & $\begin{array}{c}0.042^{* * *} \\
(0.005)\end{array}$ & $\begin{array}{l}0.044^{* * * *} \\
(0.005)\end{array}$ \\
\hline$R O A$ & $\begin{array}{l}4.221^{* * * *} \\
(0.198)\end{array}$ & $\begin{array}{c}4.206^{* * *} \\
(0.198)\end{array}$ & $\begin{array}{l}5.247^{* * *} \\
(0.191)\end{array}$ \\
\hline PastRet & $\begin{array}{c}-0.117^{* * *} \\
(0.016)\end{array}$ & $\begin{array}{c}-0.119^{* * * *} \\
(0.016)\end{array}$ & $\begin{array}{c}-0.146^{* * *} \\
(0.015)\end{array}$ \\
\hline Analyst_Following & $\begin{array}{c}0.081^{* * *} \\
(0.014)\end{array}$ & $\begin{array}{c}0.082^{* * *} \\
(0.014)\end{array}$ & $\begin{array}{l}0.078^{* * * *} \\
(0.013)\end{array}$ \\
\hline _cons & $\begin{array}{c}-0.899^{* * * *} \\
(0.092)\end{array}$ & $\begin{array}{c}-0.888^{* * * *} \\
(0.092)\end{array}$ & $\begin{array}{c}-0.549^{* * * *} \\
(0.089)\end{array}$ \\
\hline Year fixed effect & YES & YES & YES \\
\hline $\mathrm{N}$ & 19,129 & 19,129 & 19,129 \\
\hline $\mathrm{R}^{2}$ & 0.045 & 0.045 & 0.126 \\
\hline
\end{tabular}

Standard errors are reported in parentheses

${ }^{*} p<0.1,{ }^{* *} p<0.05,{ }^{* * *} p<0.01$

Similarly, we also split our sample into two groups based on the value of Decrease. Then we redo the Fisher's Permutation test to explore different effects of professional connections within analyst teams on forecast accuracy when firms are in different environment. As is shown in Table 7, Conn_index is positively associated with Accuracy in both column 1 $\left(\beta_{1}=0.067\right)$ and column $2 \quad\left(\beta_{1}=0.290\right)$. And the coefficient of Conn index is much larger when firms face declining EPS. The difference between coefficients of Conn_index in two groups is significant according to Fisher's Permutation test. Therefore, our main result is robust and professional connections will have stronger impact on forecast accuracy when firms are in bad environment as there are more information and noise for analysts to process.
Table 7. Effects of connection index on forecast accuracy in different development envi ronment

\begin{tabular}{|c|c|c|c|c|}
\hline Variables & Decrease $=0$ & Decrease $=1$ & Diff & $p$-value \\
\hline Conn_inde & $0.067^{* *}$ & $0.290^{* * *}$ & -0.223 & 0.000 \\
\hline$x$ & $(0.030)$ & $(0.083)$ & & \\
\hline \multirow[t]{2}{*}{ Star } & $-0.062^{* * *}$ & -0.084 & \multirow[t]{2}{*}{0.022} & \multirow[t]{2}{*}{0.392} \\
\hline & $(0.028)$ & $(0.070)$ & & \\
\hline \multirow{4}{*}{$\begin{array}{l}\text { Brokerage } \\
\text { Size } \\
\text { Experience }\end{array}$} & -0.010 & -0.024 & \multirow[t]{2}{*}{0.014} & \multirow[t]{2}{*}{0.384} \\
\hline & $(0.016)$ & $(0.043)$ & & \\
\hline & $-0.091^{* * * *}$ & $-0.514^{* * * *}$ & 0.423 & 0.000 \\
\hline & $(0.021)$ & $(0.059)$ & & \multirow{3}{*}{0.009} \\
\hline \multirow[t]{2}{*}{ No_Firms } & $0.021^{* *}$ & -0.039 & \multirow[t]{2}{*}{0.061} & \\
\hline & $(0.011)$ & $(0.028)$ & & \\
\hline \multirow[t]{2}{*}{$B M$} & $0.029^{* * * *}$ & $0.064^{* * *}$ & \multirow[t]{2}{*}{-0.035} & \multirow[t]{2}{*}{0.000} \\
\hline & $(0.005)$ & $(0.010)$ & & \\
\hline \multirow[t]{2}{*}{$R O A$} & $4.359^{* * *}$ & $7.150^{* * *}$ & \multirow[t]{2}{*}{-2.792} & \multirow[t]{2}{*}{0.000} \\
\hline & $(0.168)$ & $(0.423)$ & & \\
\hline \multirow[t]{2}{*}{ PastRet } & -0.005 & $-0.327^{\text {*** }}$ & \multirow[t]{2}{*}{0.322} & \multirow[t]{2}{*}{0.000} \\
\hline & $(0.014)$ & $(0.031)$ & & \\
\hline Analyst_ & $0.032^{* * * *}$ & $0.184^{* * *}$ & -0.152 & 0.000 \\
\hline Following & $(0.011)$ & $(0.031)$ & \multirow{3}{*}{0.597} & \multirow{3}{*}{0.002} \\
\hline \multirow[t]{2}{*}{ _cons } & $-0.643^{* * *}$ & $-1.241^{* * * *}$ & & \\
\hline & $(0.075)$ & $(0.204)$ & & \\
\hline $\begin{array}{l}\text { Year fixed } \\
\text { effects }\end{array}$ & YES & YES & & \\
\hline $\mathrm{N}$ & 12,175 & 6,954 & & \\
\hline $\mathrm{R}^{2}$ & 0.072 & 0.078 & & \\
\hline
\end{tabular}

\section{Conclusions}

The purpose of this study is to examine the relationship between professional connections within analyst teams and their earnings forecast accuracy, and try to figure out the different effects of professional connections in forecast generating process when firms are in different environment.

Following Ke et al. (2019), we construct a dummy variable to gauge the connections between analysts, and calculate a continuous index of connections to test the robustness of our results [42]. The forecast accuracy is used to measure security analyst performance. We get two main findings through empirical analysis of the dataset of earnings forecasts issued from 2016 to 2017. Firstly, professional connections within analyst teams are helpful in forecast generating and could improve the quality of forecasts issued by analyst teams, supporting Hypothesis 1. Additionally, we find that professional connections would be more influential to forecast accuracy when firms face decreasing earnings according to the results of Fisher's Permutation test, and confirm Hypothesis 2. Our result is robust to alternative measurement of professional connections.

\section{Discussions}


Our study makes several theoretical contributions. First, different from most of literatures focusing analystlevel heterogeneity [7, 29, 44, 54], this work enriches previous literature related to analyst performance by concentrating on the characteristics of analyst teams. Second, by introducing the effect of professional connections to the context of sell-side analyst forecast, we provide a novel insight into factors influencing the analyst forecast. Future studies can explore impacts of other types of connection or network within analyst teams on team performance based on this work. Finally, we demonstrate that connections within analyst play an important role in analysts' earnings forecast, and its effect will be stronger while the forecasted firms are facing descending EPS. We laid the foundation for further investigation about the impacts of connections on team performance under various situation.

Our work also has some practical implications. On one hand, our findings provide practical guidance to brokerage houses in terms of how to allocate analysts. Specifically, brokerage houses should try to take advantage of connections among analysts to improve their performance when constructing analyst teams, especially when firms they forecast are in bad times. On the other hand, analyst teams with connections should be highly valued and trusted by investors, especially when the firms they focus on are facing descending EPS.

However, our study has some limitations due to the dataset and measurements of variables. Firstly, we only conduct analysis on data of earnings forecast during the period from 2016 to 2017 . We will try to test our assumption and generalize our conclusions based on larger sample in future studies. Secondly, we employ the forecast accuracy to reflect analyst performance in this study. However, analysts also comment on and issue recommendation of stocks [56] in addition to earnings forecast. Therefore, the quality of recommendation $[8$, $35]$ is an alternative proxy for analyst performance in future studies. Thirdly, we gauge professional connections based on analysts' employment in this study. However, there are other kinds of connections among analysts which could be taken into consideration for more comprehensive understanding of the analyst network [16, 21, 24].

Considering the important role of security analyst teams, future research could explore the impact of other characteristics of analyst teams on their research reports and the stock market. Focus on the importance of connections among analysts, further studies could also extend the definition of connections for further understanding the important role of connections. Besides, we will try to dig more to examine the underlying mechanism with identification strategies in the future.

\section{Acknowledgements}

The authors would like to thank the editor and reviewers for their helpful and constructive suggestions. This research was supported by the National Natural Science Foundation of China (Grant \# 71532004, 71801063, 71490724, and 71850013) and the China Postdoctoral Science Foundation (Grant \# 2018M640300).

\section{References}

[1] A., H. 1995. Improving group judgment accuracy: Information sharing and determining the best member. Organizational Behavior and Human Decision, 62(2), pp. 190197.

[2] Ahern, K. R. and Sosyura, D. 2015. Rumor has it: Sensationalism in financial media. The Review of Financial Studies, 28(7), pp. 2050-2093.

[3] Ali, A., Li, N., and Zhang, W. 2015. Restrictions on managers' outside employment opportunities and asymmetric disclosure of bad versus good news. The Accounting Review. [4] Baginski, S. P., Campbell, J. L., Hinson, L. A., and Koo, D. S. 2018. Do career concerns affect the delay of bad news disclosure? The Accounting Review, 93(2), pp. 61-95.

[5] Beal, D. J., Cohen, R. R., Burke, M. J., and McLendon, C. L. 2003. Cohesion and performance in groups: A metaanalytic clarification of construct relations. Journal of Applied Psychology, 86(6), pp. 989-1004.

[6] Boni, L. and Womack, K. L. 2006. Analysts, industries, and price momentum. Journal of Financial and Quantitative Analysis, 41(1), pp. 85-109.

[7] Bradley, D., Gokkaya, S., and Liu, X. I. 2017. Before an analyst becomes an analyst: Does industry experience matter? The Journal of Finance, 72(2), pp. 751-792.

[8] Bradley, D., Clarke, J., Lee, S., and Ornthanalai, C. 2014. Are analysts' recommendations informative? Intraday evidence on the impact of time stamp delays. The Journal of Finance, 69(2), pp. 645-673.

[9] Brown, L. D., Call, A. C., Clement, M. B., and Sharp, N. Y. 2015. Inside the "black box" of sell-side financial analysts. Journal of Accounting Research, 53(1), pp. 1-47.

[10] Bunderson, J. S. and Sutcliffe, K. M. 2002. Comparing alternative conceptualizations of functional diversity in management teams: Process and performance effects. Academy of Management Journal, 45(5), pp. 875-893.

[11] Buyl, T., Boone, C., Hendriks, W., and Matthyssens, P. 2011. Top management team functional diversity and firm performance: The moderating role of ceo characteristics. Journal of Management Studies, 48(1), pp. 151-177.

[12] Chen, Y., Cheng, C. S. A., Li, S., and Zhao, J., Media attention and selective managerial bad news hoarding. SSRN. [13] Cleary, S. 1999. The relationship between firm investment and financial status. The Journal of Finance, 54(2), pp. 673-692.

[14] Clement, M. B. 1999. Analyst forecast accuracy: Do ability, resources, and portfolio complexity matter? Journal of Accounting and Economics.

[15] Clement, M. B. and Tse, S. Y. 2003. Do investors respond 
to analysts' forecast revisions as if forecast accuracy is all that matters? The Accounting Review, 78(1), pp. 227-249.

[16] Cohen, L., Frazzini, A., and Malloy, C. 2010. Sell-side school ties. The Journal of Finance, 65(4), pp. 1409-1437.

[17] Cross, R. and Parker, A., The hidden power of social networks: Understanding how work really gets done in organizations. 2004, Boston: Harvard Business School Press.

[18] Dahlin, K. B., Weingart, L. R., and Hinds, P. J. 2005. Team diversity and information use. Academy of Management Journal, 64(6), pp. 1107-1123.

[19] Diether, K., Malloy, C., and Scherbina, A. 2002. Differences of opinion and the cross section of stock returns. The Journal of Finance, 57(5), pp. 2113-2141.

[20] Efron, B. and Tibshirani, R. J., An introduction to the bootstrap. 1994, United States of America: CRC press.

[21] El-Khatib, R., Fogel, K., and Jandik, T. 2015. CEO network centrality and merger performance. Journal of Financial Economics, 116(2), pp. 349-382.

[22] Engelberg, J., Gao, P., and Parsons, C. A. 2012. Friends with money. Journal of Financial Economics, 103(1), pp. 169188.

[23] Ertimur, Y., Muslu, V., and Zhang, F. 2011. Why are recommendations optimistic? Evidence from analysts' coverage initiations. Review of Accounting Studies, 16(4), pp. 679-718.

[24] Fracassi, C. and Tate, G. 2012. External networking and internal firm governance. The Journal of Finance, 67(1), pp. 153-194.

[25] Frankel, R., Kothari, S. P., and Weber, J. 2006. Determinants of the informativeness of analyst research. Journal of Accounting and Economics, pp. 29-54.

[26] Grossman, S. J. and Stiglitz, J. E. 1980. On the impossibility of informationally efficient markets. The American Economic Review, 70(3), pp. 393-408.

[27] Hilary, G. and Hsu, C. 2013. Analyst forecast consistency. The Journal of Finance, 68(1), pp. 271-297.

[28] Hinsz, V. B., Tindale, S., and Vollrath, D. A. 1997. The emerging conceptualization of groups as information processes. Psychological Bulletin, 121(1), pp. 43-64.

[29] Hong, H. and Kubik, J. D. 2003. Analyzing the analysts: Career concerns and biased earnings forecasts. The Journal of Finance, 58(1), pp. 313-351.

[30] Hong, H. and Kacperczyk, M. 2010. Competition and bias. The Quarterly Journal of Economics, 125(4), pp. 1683-1725.

[31] Hong, H., Lim, T., and Stein, J. C. 2000. Bad news travels slowly: Size, analyst coverage, and the profitability of momentum strategies. The Journal of Finance, 55(1), pp. 265295.

[32] Hope, O. K. and Kang, T. 2005. The association between macroeconomic uncertainty and analysts' forecast accuracy. Journal of International Accounting Research, 4(1), pp. 23-38. [33] Jagiello, R. D. and Hills, T. T. 2018. Bad news has wings: Dread risk mediates social amplification in risk communication. Risk Analysis, 38(10), pp. 2193-2207.

[34] Jegadeesh, N. and Kim, W. 2010. Do analysts herd? An analysis of recommendations and market reactions. The Review of Financial Studies, 23(2), pp. 901-937.

[35] Jegadeesh, N., Kim, J., Krische, S. D., and Lee, C. M. C. 2004. Analyzing the analysts: When do recommendations add value? The Journal of Finance, 59(3), pp. 1083-1124.

[36] Jehn, K. A. and Shah, P. P. 1997. Interpersonal relationships and task performance: An examination of mediation processes in friendship and acquaintance groups. Journal of Personality and Social Psychology, 72(4), pp. 775790 .

[37] Jiang, H. and Verardo, M. 2018. Does herding behavior reveal skill? An analysis of mutual fund performance. The Journal of Finance, 73(5), pp. 2229-2269.

[38] Jones, B. F. 2009. The burden of knowledge and the "death of the renaissance man": Is innovation getting harder? The Review of Economic Studies, 76(1), pp. 283-317.

[39] Jung, M. J., Naughton, J. P., Tahoun, A., and Wang, C. 2018. Do firms strategically disseminate? Evidence from corporate use of social media. The Accounting Review, 93(4), pp. 225-252.

[40] Kadan, O., Madureira, L., Wang, R., and Zach, T. 2012. Analysts' industry expertise. Journal of Accounting and Economics, 54(2-3), pp. 95-120.

[41] Ke, B. and Yu, Y. 2006. The effect of issuing biased earnings forecasts on analysts' access to management and survival. Journal of Accounting Research, 44(5), pp. 965-999. [42] Ke, R., Li, M., Ling, Z., and Zhang, Y. 2019. Social connections within executive teams and management forecasts. Management Science, 65(1), pp. 439-457.

[43] Kothari, S. P., Susanshu, and Wysocki, P. D. 2009. Do managers withhold bad news? Journal of Accounting Research, 47(1), pp. 241-275.

[44] Li, X., Sullivan, R. N., Xu, D., and Gao, G. 2013. Sellside analysts and gender: A comparison of performance, behavior, and career outcomes. Financial Analysts Journal, 69(2), pp. 83-94.

[45] Lim, T. 2001. Rationality and analysts'forecast bias. The Journal of Finance, 56(1), pp. 369-385.

[46] Livnat, J. and Zhang, Y. 2012. Information interpretation or information discovery: Which role of analysts do investors value more? Review of Accounting Studies, 17(3), pp. 612641.

[47] Lo, K. 2012. What do analysts do? Discussion of "information interpretation or information discovery: Which role of analysts do investors value more?". Review of Accounting Studies, 17(3), pp. 642-648.

[48] Loh, R. K. and Stulz, R. M. 2011. When are analyst recommendation changes influential? The Review of Financial Studies, 24(2), pp. 593-627.

[49] Loh, R. K. and Stulz, R. M. 2018. Is sell-side research more valuable in bad times? The Journal of Finance, 73(3), pp. 959-1013.

[50] Malloy, C. J. 2005. The geography of equity analysis. The Journal of Finance, 60(2), pp. 719-755.

[51] Malmendier, U. and Shanthikumar, D. 2007. Are small investors naive about incentives? Journal of Financial Economics, 85(2), pp. 457-489.

[52] Marquaridt, D. W. 1970. Generalized inverses, ridge regression, biased linear estimation, and nonlinear estimation. Technometrics, 12(3), pp. 591-612.

[53] McPherson, M., Smith-Lovin, L., and MCook, J. 2001. Birds of a feather: Homophily in social networks. Annual Review of Sociology, 27, pp. 415-444.

[54] Merkley, K., Michaely, R., and Pacelli, J. 2017. Does the scope of the sell-side analyst industry matter? An examination of bias, accuracy, and information content of analyst reports. The Journal of Finance, 72(3), pp. 1285-1334. 
[55] Mesmer-Magnus, J. R. and Dechurch, L. A. 2009. Information sharing and team performance: A meta-analysis. Journal of Applied Psychology, 94(2), pp. 535-46.

[56] Michaely, R. and Womack, K. L. 1999. Conflict of interest and the credibility of underwriter analyst recommendations. The Review of Financial Studies, 12(4), pp. 653-686.

[57] Mikhail, M. B., Walther, B. R., and Willis, R. H. 1997. Do security analysts improve their performance with experience? Journal of Accounting Research, 35, pp. 131-157.

[58] Mikhail, M. B., Walther, B. R., and Willis, R. H. 2007. When security analysts talk, who listens? The Accounting Review, 82(5), pp. 1227-1253.

[59] Niessner, M. and So, E. C., Bad news bearers: The negative tilt of the financial press. SSRN.

[60] Rogers, E. M. and Bhowmik, D. K. 1970. Homophilyheterophily: Relational concepts for communication research. Public Opinion Quarterly, 34(4), pp. 523-538.

[61] Schittekatte, M. and Hiel, A. V. 1996. Effects of partially shared information and awareness of unshared information on information sampling. Small Group Research, 27(3), pp. 431449.

[62] Simsek, Z., Veiga, J. F., Lubatkin, M. H., and Dino, R. N.
2005. Modeling the multilevel determinants of top management team behavioral integration. Academy of Management Journal, 48(1), pp. 69-84.

[63] Singh, J. and Fleming, L. 2010. Lone inventors as sources of breakthroughs: Myth or reality? Management Science, 56(1), pp. 41-56.

[64] Sonney, F. 2009. Financial analysts' performance: Sector versus country specialization. The Review of Financial Studies, 22(5), pp. 2087-2131.

[65] Trueman, B. 1994. Analyst forecasts and herding behavior. The Review of Financial Studies, 7(1), pp. 97-124.

[66] Van Knippenberg, D., De Dreu, C. K. W., and Homan, A. C. 2004. Work group diversity and group performance: An integrative model and research agenda. Journal of Applied Psychology, 89(6), pp. 1008-1022.

[67] Williams, P. A. 1993. The relation between a prior earnings forecast by management and analyst response to a current management forecast. The Accounting Review, 71(1), pp. 103-113.

[68] Womack, K. L. 1996. Do brokerage analysts' recommendations have investment value? The Journal of Finance, 51(1), pp. 137-167. 